\title{
衛生害虫分野における薬剂利用
}

\author{
安富和男
}

国立予防衛生研究所衛生昆虫部

（昭和 54 年. 12 月 24 日受理）

\section{Insecticidal Control for Insects of Medical Importance in Japan}

\author{
Kazuo YasuTomi \\ Department of Medical Entomology, National Institute of \\ Health, Shinagawa-ku, Tokyo 141, Japan
}

\section{衛生害虫の定義とその变遷}

衛生害虫とは，いうまでもなく人体に何らかの衛生上 の害を与光る昆虫の総称であるが，国により，時代によ り解勫が異なるし，变遷がみられる，最も重要な衛生害 虫は伝染病の媒介者 (vector) と運搬者（carrier）であ り，ついで，吸血害虫，刺咬害虫，皮膚炎を起す害虫が 挙げられるが, 近年, 不快害虫 (nuisance) が駆除対象 として大きな割合を占めるようになってきた.

不快感の評価は人により土地によって異なるし，また 時代の影響を大きく受ける，国によっては，危険な伝染 病を媒介するものだけが衛生害虫であるが，現在の日本 では，とくに伝染病とは関係がうすくても，八エ・ゴキ ブリはもちろんのこと, 都市河川や湖沼から発生するユ スリカ類, ビール工場や港湾の貯木場から発生するクロ ショウジョウバエ, 浄化槽のチョウバエ類, 越冬のため 人家へ飛来するカメムシ類なども衛生害虫として駆除対 象になる. とくに近年, 都市化が進むにつれて, ビルの 地下の溜り水や浄化槽を発生源とするチカイエカや，污 泥埋立地から大発生する八マベ八ヤトビバェなどの新ら しい衛生害虫が問題になってきたし，ごみ埋立地におけ る抵抗性イエバェ対策も重要な課題である.

食品害虫や, 昆虫以外の節足動物ではコナダニやヒョ ウヒダニなどのダニ類，ムカデ，ゲジゲジ，ヤスデ類も 広義の衛生害虫として取り扱われている.

\section{殺虫㨈利用の歴史}

古い時代の衛生害虫防除は植物の利用から始まった。 ショウブ（葛蒲）で作ったムシロにはノミがつかないと され，ヨモギやミカンの皮をいぶした“かやり火”を作 ってカを防いだ.

明治 18 年に除虫菊の種子が輸入され，明治 24 年頃に は“ノミ取り粉”として除虫菊粉が用いられるようにな り，やがて “蚊取線香” に製戍化された，その後，蚊取 線香の成分は一部，合成のアレスリンに置き換えられは したが, 現在まで家庭用殺虫凨の花形として賞用されて いる，昭和に入って，ゴキブリ退治のための食毒として 研酸団子が用いられるようになり, 昭和 10 年代には, ピレトリン油剤とオルソ剤 (ゾール剤) が登場, 普及し た.

オルソ剂とは，オルソジクロールベンゼンを50 70\% 含む日本独特の殺虫郕であり, 汲取便所の便槽の殺菌・ 殺蛆郕として現在に至るまで需要が多い，その理由とし ては, 蛆にかなりの速効性があること, 抵抗性の発達が ほとんどないこと，また，消毒臭が好まれることなどが 考えられる.

第 2 次大戦後殺虫剤の様相は一変し, 有機合成殺虫棛 の時代になった。昭和 20 年にまずアメリカ軍によって DDT がもちこまれて, 都市に航空散布されたり,コロ モジラミやアタマジラミ駆除のために, 衣服や頭髮に処 理されたりした．DDT の国産化は昭和 22 年に始まり, 衛生害虫分野に扮いても, 昭和 20 年代後半は DDT 全 
盛時代の観を呈していた，当時，衛生害虫分野で使用さ れた DDT はその 80\% が油剤 (DDT工業製品原体 5\% を含むケロシン液) であり，10\% が粉剤，残りが乳威 や水和剤，ペーストに製剂化されていた，南方のマラリ ア・コントロールには水和剤が多量に用いられたが，日 本に颃いては水和剤を残留噴霧すると屋内にしみをつけ るという理由で敬遠された，油剤が多用されたのは日本 的な特徵の一つといえよう。

昭和 24 年には， $\gamma$-BHC を $99 \%$ 以上含むリソデンが 防疫用として許可され，20 年代末には単剤，あるいは DDT との混合剤が普及した。農林害虫分野と異なり, 衛生害虫分野においては，BHC は，大体リンデンのか たちとしてのみ用いられてきた点をとくに記しておきた い. 昭和 30 年頃, 最も広く用いられた殺虫剤は，5\% DDT・ $0.2 \%$ リンデン・0.05\% ピレトリン混合油剤で あって，通称 3 種混合油剤といわれた。欧米の人には， DDT になぜピレトリンを配合しなければならないのか という疑問をいだかせたようであるが，速効性を好む日 本では，その後も DDT DDVP が配合された製剤も 登場するに至った。

昭和 30 年にはディルドリン，33 年にはクロルデンが 厚生省の製造承認を受けて，ゴキブリ駆除㓮として残留 処理されるようになった。

昭和 30 年 6 月から厚生省の提唱による「蚊と八エの いない生活実践運動」が推進され，地区組織を基盤にし た活動が全国的に浸透した.

昭和 31 年にダイアジノン，32〜33 年にはマラチオン (マラソン) とジクロルボス (DDVP), ついで, トリク ロルホン（ディプテレックス），フェニトロチオン（ス ミチオン)，フェンチオン（バイテックス）など, 近年 ではテメホス（アベイト），ピリダフェンチオン（オフ ナック）などの有機燐剤がつぎつぎに許可承認され，有 機燐剂中心の時代に移行した.

昭和 46 年 (1971) に DDT などの塩素系殺虫剤は販 売禁止および制限措置がとられ使用されなくなったのは 衆知のことであるが，デンマークなどでは，DDT やリ ンデンは抵抗性のために，すでに 1950 年頃から衛生害 虫の分類から姿を消している.

合成ピレスロイドは昭和 27 年にアレスリン，昭和 39 年にフタルスリンが, 近年になって，フラメトリン，レ スメトリン，フェノトリン，゚ルメトリンがつぎつぎに 登場してきた. ピレスロイド系殺虫戍は数年前まではも っぱら家庭用殺虫剤（エアゾール，蚊取線香など）専用 の観があったけれども，最近では，単剤，あるいは有機 燐剤との混合で乳剤などに製剤化され，防疫用薬剤とし
ての面に進出を始めている．また，ペルメトリンはエア ゾール，乳剤のほか，燻煙剤の成分として用いられ，そ の追い出し効果 (flushing effect) が，ゴキブリ，カメム シなどで大きな注目を集めるようになった。 また，ピレ スロイド系殺虫剤は有機燐剤抵抗性の衛生害虫に対して 交差抵抗性がないので，今後の発展が期待されている.

日本における衛生害虫分野に利用される殺虫剂を諸外 国と比較すると，前にも述べたように，速効性がとくに 歓迎されるので, フェニトロチオン，フェンチオン（バ イテックス)，あるいはダイアジノンなどにジクロルボ ス (DDVP) が配合された有機燐剤同志の 2 種混合の乳 剂や油刜が最も普遍的に利用されている傾向がある。 た，たんに速効性を与えるだけでなく，最近登場したピ リダフェンチオン・ジクロルボスの混合剤や, フェニト ロチオン・フタルスリンの混合郕のように, 抵抗性イエ バェに対する相委作用が認められる配合もあるのは注目 すべき方向といえよう。

1960 年代までの防疫用殺虫剤にとって具備すべき条 件の第一は，害虫に対するすぐれた殺虫力であったけれ ども，1970 年代に入って，しだいに人畜低毒性が第一 に要望される傾向に変ってきたことも時の流れからみて も当然のことであろう.

\section{衛生害虫用（防疫用・家庭用）殺虫剂の成分}

現在, 衛生害虫駆除のために用いられている薬剤を表

表 1 衛生害虫用殺虫剤等一覧

\begin{tabular}{|c|c|}
\hline 薬剤の系統 & 薬剂 \\
\hline ピレスロイド類 & $\begin{array}{l}\text { ピレトリン, アレスリン, フタルス } \\
\text { リン, フラメトリン, レスメトリ } \\
\text { ソ, プロパルトリン, フェノトリ } \\
\text { ソ, ペルメトリン }\end{array}$ \\
\hline 有 機 燐 剂 & $\begin{array}{l}\text { ダイアジノン, マラチオン, ジクロ } \\
\text { ルボス, トリクロルホン, ロンネ } \\
\text { ル, ナレド, フェニトロチオン, フ } \\
\text { ェンチオン, テメホス, シアホス, } \\
\text { カルクロホス, ブロモホス, ピリダ } \\
\text { フェンチオン, クロルピリホスメチ } \\
\text { ル }\end{array}$ \\
\hline カーバメート采 & ジメチラン \\
\hline 塩 素系薬 郕 & オルソジクロルベンゼン \\
\hline 剂 & $\begin{array}{l}\text { オクタクロロジプロピルエーテル } \\
(\mathrm{S}-421), \quad \text { サネピリン } 500, \quad \text { サイ } \\
\text { ネピリソ } 222 \text { (シネトリン, MGK- } \\
264), \text { ピペロニルブトキサイド, チ } \\
\text { オシアノ酢酸イソボルニル (IBTA) }\end{array}$ \\
\hline
\end{tabular}


表 2 各種殺虫剂の衛生害虫類に対する致死効力

\begin{tabular}{|c|c|c|c|c|c|c|c|}
\hline 薬 & $\begin{array}{l}\text { イエバェ } \\
\text { 成 } \\
\left(\mathrm{LD}_{50}\right) \\
(\mu \mathrm{g} / \text { 虫 }\end{array}$ & $\begin{array}{c}\text { アカイエカ } \\
\text { 成 } \\
\left(\mathrm{LD}_{50}\right) \\
(\mu \mathrm{g} / \text { 虫 })\end{array}$ & $\begin{array}{c}\text { アカイエカ } \\
\text { 幼 } \\
\left(\mathrm{LC}_{50}\right) \\
(\mathrm{ppm})\end{array}$ & $\begin{array}{c}\text { チャバネゴ } \\
\text { キブリ成虫 } \\
\left(\mathrm{LD}_{50}\right) \\
(\mu \mathrm{g} / \text { 安 })\end{array}$ & $\begin{array}{c}\text { センチニク } \\
\text { バエ幼虫 } \\
\left(\mathrm{LC}_{50}\right) \\
(\mathrm{ppm})\end{array}$ & $\begin{array}{c}\text { オオチョウ } \\
\text { バ I成虫 } \\
\left(\mathrm{LD}_{50}\right) \\
(\mu \mathrm{g} / \text { 早 })\end{array}$ & $\begin{array}{c}\text { オオチ品 } \\
\text { 江幼虫 } \\
\left(\mathrm{LC}_{50}\right) \\
(\mathrm{ppm})\end{array}$ \\
\hline マラチオン & 0.24 & 0.011 & 0.095 & 0.48 & $>100$ & 0.0181 & 3.68 \\
\hline ダイアジノン & 0.018 & 0.010 & 0.032 & 0.39 & 5.2 & 0.0208 & 1.41 \\
\hline フェニトロチオン & 0.029 & 0.0030 & 0.0068 & 0.25 & 3.1 & 0.0041 & 0.36 \\
\hline フェンチオン & 0.028 & 0.0006 & 0.0021 & 0.33 & 2.9 & 0.0013 & 0.45 \\
\hline ジクロルボス & 0.013 & 0.0039 & 0.029 & 0.15 & 3.6 & 0.0015 & 3.48 \\
\hline アレスリン & 0.201 & 0.0251 & 0.22 & 1.99 & 50.0 & 0.0294 & 1.73 \\
\hline フタルスリン & 0.162 & 0.0246 & 0.107 & 1.12 & - & 0.0091 & 7.04 \\
\hline
\end{tabular}

(鈴木，林，安富のデーターより作成)

1 にとりまとめてみたが, 有機燐戍とピレスロイド系殺 虫剂が中心となっている，以下，それぞれの概要を解説 したい.

\section{1. 塩素系殺蛳}

オルソジクロールベンゼン： 50 70\% 含有の乳郕 （オルソ剂）に製剂化され，便池の殺蛆剂と代用消毒薬の 両面から広く使用されている。殺蛆には 50 倍希釈液を $1 \mathrm{~m}^{2}$ 当たり $2 l$ の割で散布する.ジクロルボス(DDVP) との混合剂もあり，この場合の希釈倍率は 100 倍程度で ある.オルソ剂は前項で述べた長所をもっているが，殺 蛆以外では効力が弱い，1 缶当たりは安価であっても 1 回の使用時の経済性では有機燐郕より高価につく, この 薬剂を使った屎尿を肥料にすると薬害を生ずることがあ るなどの短所もある。

\section{2. 有機燐剤}

ダイアジノン：、エ，カ，ゴキブリなどに対して比 較的速効性で，効力の持続期間もかなり長く，広く使わ れている.

マラチオン（マラソン）：人畜低毒性. やや遅効性. 特有の臭気のためか, 日本では衛生害虫用にあまり量的 に使用されていない。

ジクロルボス (DDVP): 速効性, 微量で効くため, 単剤のほか, 他の有機燐剤に配合されてきわめて広く使 用されている. 蒸気圧が大きいので残効性は期待できな いが, 樹脂蒸散剂として特徵が活かされた利用がなされ ている.

トリクロルホン（ディプテレックス）：人畜低毒性, 低魚毒性が注目され, 乳剂などのほか, 可溶化タイプの 䍑型（アルコール液）もある.

ロンネル（ナンコール）：人畜低毒性. やや遅効性で あるが，残効性が比較的長い。

ナレド（シブロム）：DDVPに近い速効性と DDVP
表 3 各種殺虫戍のイエバエ成虫に対する速効性

$\left(\mathrm{KT}_{50}\right.$ 值 $)$

\begin{tabular}{lccc}
\hline 供 試 薬 剂 & $\begin{array}{c}0.5 \% \\
(\text { 分) }\end{array}$ & $\begin{array}{c}0.25 \% \\
(\text { 分) }\end{array}$ & $\begin{array}{c}0.125 \% \\
\text { (分) }\end{array}$ \\
\hline マラチチオ & 31 & 34 & 39 \\
ダイフジノン & 7 & 8 & 14 \\
フェニトロチオソ & 12 & 15 & 16 \\
フェンチオン & 25 & 28 & 31 \\
ディプテレックス & 38 & 39 & 66 \\
ジクロルボス & 2 & 4 & 5 \\
ナ レ & 4 & 5 & 8 \\
\hline
\end{tabular}

$0.5 \mathrm{ml}$ 噴霧降下法（林, 1976 より）

よりやや長い残効性をもつ，眼や鼻に対する刺戟が強い せいか, 衛生害虫用としては使用量が少ない。

フェニトロチオン： 人畜低毒性. やや遅効性である が, 残効性が長く, 各種衛生害虫の成虫対策にも幼虫対 策にも広く使われている.

フェンチオン (バイテックス)：各種の衛生害虫に有 効で残効性も長く，とくに力（幼虫・成虫）に対する効 力が顕著であるので，広く使用されている．人畜毒性む 低いほうである.

テメホス（アベイト）： カの幼虫(ボウフラ），ユスリ カの幼虫 (アカボウフラ), ブニの幼虫など水棲の双趐 目の幼虫に選択的な効果を示す. 人畜低毒性.

シアホス（サイノック）：人畜低毒性で，ゴキブリや 八エに対する殺虫力が強い.

カルクロホス（クレカルビン）：DDVP に近い速効 性と, DDVP ょりやや長い残効性をもち, 原体が水に よく溶けるので $5 \%$ 水溶剤 (白色粉末) に製剂化されて いる.

ブロモホス：人畜低毒性. 成虫用より larvicide と してすぐれている. 
ピリダフェンチオン（オフナック）：人畜低毒性. 広 範囲の衛生害虫に有効で将来性が期待されている.

クロルピリホスメチル (ザーテル): 人畜低毒性. ボ ウフラを始め広範囲の衛生害虫に有効である。

\section{3. ピレスロイド系殺虫剤}

ピレトリン：速効性が強いが，ノックダウンした虫 が蘇生する傾向がある. 残効性はほとんど期待できな い. 油剂, エアゾール，乳剂，蚊取線香に製戍化され， 他のビレスロイドや共力剤との混合剤が多い。

アレスリン： 殺虫力の特徵はピレトリンによく似て おり, 蚊取線香, 電気蚊取器, エアゾールに広く用いら れている。

フタルスリン：速効性がきわめて強いが，ノックダ ウン個体の蘇生がみられる。油剤, エアゾール, 乳剤に 他剤や共力剤と配合して製剤化されている.

フラメトリン：速効性, 致死効力がアレスリンより ややすぐれ，蒸気压がピレスロイド中最も高いので，加 熱蒸散に適しており, 蚊取線香, 電気蚊取器などに向い ている.

レスメトリン：イエバエ，アカイエカの成・幼虫な ぞ衛生害虫類に対する致死効力がきわめて大きく（微量 で有効)，ノックダウンした虫の蘇生がほとえどない。 残効性も他のピレスロイドにくらべて大きいが，初期の ノックダウン効果はやや劣る. 現在, 他のピレスロイド や共力剤との混合の形でェアゾールの成分に用いられて いるが，単剤，あるいは混合剤としての乳斉などに大き な将来性がある.

プロパルトリン（キクスリン）：蚊取線香の成分に適 している.

フェノトリン（スミスリン）：致死効力が高く，長期 間の残渣接触効果が期待できるピレスロイドである。工 アゾール，油剤，乳剤向きである.

ペルメトリン (エクスミン)：フェノトリンと近似し た強い殺虫力を示すピレスロイドで，エアゾール，油

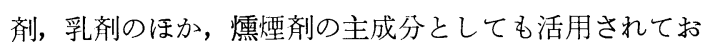
り, 将来性も大きい. とくに, 追い出し効果が注目され ている.

\section{4. カーバメート系殺虫剤}

ジメチランのフライマットのみが厚生省の許可承認を 受けている唯一のカーバメート郕であるが，ほとんど実 用化されていない.

\section{5. 共力 剂}

表 1 に示すような共力剤が，現在ピレスロイド類に配 合されている. 将来, 有機燐剤などに対する抵抗性を打 破できる共力剂の開発，実用化が切望される.

\section{6. 忌 避 剤}

ジェチルトルアミド（ディート）：エアゾール，ある いはクリーム状のかたちに製剤化され，皮膚や衣服に処 理して吸血昆虫を忌避させる効果がある. 主としてカ, ブユを対称とするが， スカカ，アブ，サシバエ，トコジ ラミ，ノミ，ツッガムシ類にも有効である. 忌避効果の 持続時間は約 3 時間である.

なお, 生理活性物質の衛生害虫に対する効力の実験研 究はわが国でも進展しており, methoprene の蚊幼虫(ボ ウフラ）に対する実用化も始まろうとしている。

\section{衛生害虫用殺虫剤の剂型}

\section{1. 油剂}

殺虫成分を白灯油（ケロシン）に溶解したもので，水 でうすめる手間を省き，そのまま使用できる簡便さのた め衛生害虫用として広く普及しているが，乳剤より経費 高につく. DDVP 油剤の煙霧は広い空間を短時間で処 理するような作業に向いている，打もな油剤の有効成分 濃度は，フェニトロチオン，マラチオン，シアホスが $1 \%$ ，ダイアジノン，トリクロルホン，フェンチオン， ナレドが $0.5 \%$ ，ジクロルボスが $0.3 \%$ であり，混合 剂も数多く市販されている.

\section{2. 乳用}

殺虫成分をキシロール，ソルベントナフサなどの溶剤 にとかし，乳化剤を加えた製剤で，いうまでもなく油剂 より高濃度の殺虫有効成分を含えでいるが，農業害虫用 の乳剂にくらべて濃度が低い，打もな乳剤の有効成分含 有濃度は，マラチオン $20 \%$, フェニトロチオン, ブロ モホス, ピリダフェンチオン, クロルピリホスメチル 10\%, ダイアジノン, ジクロルボス, フェンチオン, テ メホス $5 \%$ である.

\section{3. 水 和 剤}

ベントナイトに殺虫成分をまぜ, 界面活性刜が加えら れた粉末で，䀣濁液を作る，ブユの幼虫駆除などに使わ れているが，日本では製剤の種類も少なく，一般的でな W.

\section{4. 粉 剂}

殺虫有効成分にタルクなどの鉱物性の粉をまぜあわせ たもので, 屋内の衛生害虫駆除のため寝具や衣類を処理 するのに適している，また，㕕い面積を短時間で処理す る作業, たとえばッッガムシ有毒地への薬剂散布などに 用いられてきた。現在市販されている招もな粉戍は，マ ラチオン, フェニトロチオン $1.5 \%$ ，ダイアジノン， ト リクロルホン，フェンチオン，ロンネル $1 \%$ である. 


\section{5. フローティング粉剤（浮遊粉剤）}

微粉状の粉末に撥水剤がコーティングしてあるので, 水面に粉の膜を形成する. 水のよどんだ深い水域のボウ フラ駆除に最適である。厚生省の基準は $1 \mathrm{~m}^{2}$ 当たり $1 \mathrm{~g}$ の割で,フェンチオンとフェニトロチオンの製剤がある.

\section{6. 粒 剂}

粒状の殺虫剤で，沈降型と浮遊型とがあり，いずれ も，おもにボウフラ駆除に用いられる．水中で徐々に殺 虫成分がとけ出し，少なくも 3 週間はボウフラに対する 効力が持続する. 沈降型は多少流れのある側溝, 浮遊型 は城の濠などに適する，散布基準は $1 \mathrm{~m}^{3}$ 当たり $1 \mathrm{ppm}$ の割合である。

\section{7. 樹脂蒸散剂}

ジクロルボスを 15〜20\% 含えだ樹脂の短冊型プレー トでこれを $30 \mathrm{~m}^{3}$ に 1 本の割で吊しておくとジク口 ルボスが徐々に蒸散して害虫を斃す。ジクロルボスの蒸 父压の大きい特性を利用したもので，開封後 3 力月効力 が期待できる．衛生害虫では，とくに浄化槽のチカイエ カ成虫詨策に有効である，布，あるいは紙製のテープ， 短冊にジクロルボスをしみこませた市販品もある.

\section{8. 雳 煙 郕}

燃焼剤に殺虫成分（ジクロルボス，あるいはペルメト リン）を加えた製剤で，殺虫剤の微粒子が煙状になって 空中に飛散する．蚊取線香は名前のようにカだけが対象 であるが，この燯煙剤のほうはゴキブリ，イエダ二，力 メムシ類を対象にする.

\section{9. 蚊取線香 - 電気蚊取器}

蚊取線香は除虫菊の乾花を粉末にしたものにたぶ粉を まぜ，マラカイトグリーン（染料）を加えて湯で練り， 压搾して渦巻型にうち抜き，陰干しで乾燥させたもので ある。近年，アレスリンなどの合成ピレスロイドが用い られることが多くなった。

電気蚊取器にはいろいろな型，方式のものがあるが， アレスリンなどを電熱により空中に揮散させるしくみで ある。

\section{0. エアゾール}

殺虫成分を溶剂にとかし，ガス（フッ化炭化水素とプ ロパソなどの混合物）とともに午につめた製剤で，ボタ ンを押すと殺虫剤の霧が噴出する.内容は 300 $500 \mathrm{ml}$, ハエ・カ用とゴキブリ用に大別される．室内の空間にス プレーするハエ・カ用にはピレスロイド系殺虫剤に共力 剤が配合されたものが主体になっている，一方，ゴキブ リ用は，ゴキブリのはいまわる所や潜み場所のまわりに 吹きつけるもので, フェニトロチオン・ジクロルボスの 混合剤を主体としていたが，最近ピレスロイド（ペルメ
トリン）を成分とし，追い出し効果 (flushing effect) を ねらったものも市敗されている。

\section{1. ベイト（毒飰）}

昆虫を誘引し，摂食させて，食毒として憋す郕型であ る. 殺虫成分としては食毒として有効なディプテレック スが主として用いられている，八工用のベイトは紙，顆 粒，錠剤など，ゴキブリ用は粉末か顆粒である。

\section{衛生害虫駆除の特徵}

衛生害虫駆除は農業害虫の防除とはやや違った性質を もっている，環境の整備，すなわち害虫の発生を許すよ うな環境を改善・整備することを本筋とし，これを「環 境的駆除」と称して，「殺虫剂による駆除」に優先させ る指導がなされてきた，殺虫剤を使用する場合も，発生 源をねらう幼虫対策のほうが成虫対策より効率がよいと 推奨される傾向がある.

現在の日本では, 衛生害虫駆除は vector control と してよりむしろ nuisance control としての色彩が強い. 農業害虫防除と違って生産との結びつきが薄いけれど も，地区衛生組織が推進母体になって“蚊と八エのいな い生活実践運動”を行ない，“住みよい鄉土建設”を目 標にするという諸外国に見られない特徴をもっている.

また，近年害虫駆除専門業者の進出がめざましく，日 本ペストコントロール協会が年々名実ともに充実してき ている現状である.

\section{殺虫剂による衛生害虫の駆除}

衛生害虫の種類, 発育ステージ, 適用場所に応じて, 殺虫有効成分，剂型を選び，効果的な使い方をしなけれ ばならない。

煙霧用や直接散布用には微量で速効性のあるジクロル ボス，八エ，力の成虫，ゴキブリに対する残効性をねら うには, フェニトロチオン，フェンチオン，ダイアジノ ンなどを選ぶ。、八幼虫 (ウジ)，力幼虫（ボウフラ）に 対しては低濃度で有効なフェンチオン，フェニトロチ才 ンなどの乳刜を用いるのが一般的であるが，水のよどえ だ深い水域のボウフラ駆除にはフェンチオンやフェニト ロチオンのフローティング粉剤を，多少流れのある側溝 のボウフラ駆除には沈降型粒剂を, 波や水田のボウフラ 駆除には浮遊型粒剤を使用すると能率的である。

厚生省の伝染病予防法施行規則には，八エ，力，ゴキ ブリなどの駆除に使用する殺虫剤の種類と使い方が付表 として揭げられている. 表 4，5 にそれを要約してとり まとめた，厚生省ではこれにもとづいて殺虫剤を使用す ることを推奨している。 
表 4 伝染病子防法施行規則で定められている各種殺虫剤の駆除対象および基準数量（油剂, 粉剂)

\begin{tabular}{|c|c|c|c|c|c|c|c|c|c|}
\hline \multirow{3}{*}{ 薬 } & \multicolumn{2}{|r|}{ 油 } & \multicolumn{2}{|l|}{ 剂 } & \multirow{3}{*}{ 薬 } & \multicolumn{2}{|r|}{ 粉 } & \multicolumn{2}{|l|}{ 剂 } \\
\hline & \multirow{2}{*}{$\frac{\text { 八工 }}{\substack{\text { 成 虫 } \\
\left(\mathrm{ml} / \mathrm{m}^{2}\right)}}$} & \multicolumn{2}{|l|}{ 蚊 } & \multirow{2}{*}{$\begin{array}{c}\text { ゴキ } \\
\text { ブリ } \\
(\mathrm{ml} / \\
\left.\mathrm{m}^{2}\right)\end{array}$} & & \multicolumn{2}{|c|}{ 八工 } & \multicolumn{2}{|c|}{ 蚊 } \\
\hline & & $\begin{array}{c}\text { 幼 虫 } \\
(\mathrm{ml} / \\
\left.\mathrm{m}^{2}\right)\end{array}$ & $\begin{array}{c}\text { 成 } \\
(\mathrm{ml} / \\
\left.\mathrm{m}^{2}\right)\end{array}$ & & & $\begin{array}{l}\text { 幼 虫 } \\
\left(\mathrm{g} / \mathrm{m}^{2}\right)\end{array}$ & $\begin{array}{l}\text { 成 虫 } \\
\left(\mathrm{g} / \mathrm{m}^{2}\right)\end{array}$ & $\begin{array}{l}\text { 幼 虫 } \\
\left(\mathrm{g} / \mathrm{m}^{2}\right)\end{array}$ & $\begin{array}{l}\text { 成 虫 } \\
\left(\mathrm{g} / \mathrm{m}^{2}\right)\end{array}$ \\
\hline $1 \%$ フェニトロチオン & $25 \sim 50$ & $5 \sim 10$ & $25 \sim 50$ & 50 & 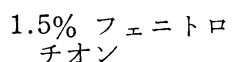 & $50 \sim 100$ & 一 & $5 \sim 15$ & $5 \sim 15$ \\
\hline \multirow[t]{2}{*}{$\begin{array}{l}0.5 \% \text { フェニトロチオン } \\
0.2 \% \text { DDVP }\end{array}$} & 7.5 & $5 \sim 10$ & 7.5 & - & & & & & \\
\hline & & & & & $1.5 \%$ マラソン & 100 & 15 & - & 15 \\
\hline 0.5\% ダイアジノン & 50 & - & 50 & - & 1\% ダイアジノン & 100 & 15 & 一 & 15 \\
\hline $\begin{array}{l}0.2 \% \text { ダイアジノン } \\
0.3 \% \text { DDVP }\end{array}$ & 5 & - & 5 & 一 & & & & & \\
\hline $0.3 \%$ DDVP & 5 & 一 & - & $2^{*}$ & & & & & \\
\hline $\begin{array}{l}0.5 \% \text { ディプテレックス } \\
0.3 \% \text { DDVP }\end{array}$ & 5 & - & 5 & - & & & & & \\
\hline $\begin{array}{l}0.5 \% \text { ナソコール } \\
0.3 \% \text { DDVP }\end{array}$ & 5 & 一 & 5 & 一 & & & & & \\
\hline $0.5 \%$ バイテックス & 50 & $5 \sim 10$ & 50 & - & 1\% バイテックス & - & - & 1 & $5 \sim 15$ \\
\hline $\begin{array}{l}0.5 \% \text { バイテックス } \\
0.2 \% \text { DDVP }\end{array}$ & 5 & $5 \sim 10$ & 5 & - & & & & & \\
\hline
\end{tabular}

* 室内空間 $1 \mathrm{~m}^{3}$ 当たり $2 \mathrm{ml}$ 煙霧

表 5 伝染病予防法施行規則で定められている各種殺虫剤の駆除対象および基準数量（乳郕）

\begin{tabular}{|c|c|c|c|c|c|c|c|c|}
\hline \multirow{3}{*}{ 薬 剂 名 } & \multicolumn{4}{|r|}{ 乳 } & \multicolumn{3}{|c|}{ 剂 } & \multirow{3}{*}{$\begin{array}{l}\text { ت゙キブリ } \\
\left(\mathrm{ml} / \mathrm{m}^{2}\right)\end{array}$} \\
\hline & \multicolumn{2}{|c|}{ 八 } & \multicolumn{2}{|l|}{ I } & \multicolumn{3}{|l|}{ 蚊 } & \\
\hline & 幼 $\left(1 / \mathrm{m}^{2}\right)$ & & $\stackrel{\text { 成 }}{(\mathrm{ml}}$ & $\left./ \mathrm{m}^{2}\right)$ & 幼 & $\stackrel{\text { 成 }}{(\mathrm{m})}$ & $1 / \mathrm{m}^{\frac{\text { 中 }}{2}}$ & \\
\hline 30倍用除虫菜 & 30倍 & 4.5 & & 一 & $\begin{array}{l}\text { 30倍 } \\
1 / 1,000 \sim 1 / 600\end{array}$ & & - & - \\
\hline $20 \%$ マラソン & 200倍 & 2 & 40倍 & 50 & 100倍 $100 \mathrm{ml} / \mathrm{m}^{2}$ & 40倍 & 50 & 10倍 50 \\
\hline 5\% ダイアジノン & 400倍 & 2 & 10倍 & 50 & 50 倍 $100 \mathrm{ml} / \mathrm{m}^{2}$ & 10倍 & 50 & 10倍 50 \\
\hline $5 \%$ DDVP & $300 \sim 500$ 倍 & 2 & 10倍 & 3 & $20 \mathrm{ml} /$ 水量 $1 \mathrm{t}$ & 10倍 & 3 & - \\
\hline $\begin{array}{l}3 \% \text { ダイアジノン } \\
2 \% \text { DDVP }\end{array}$ & 400 倍 & 2 & 10倍 & 5 & $20 \mathrm{ml} /$ 水量 $1 \mathrm{t}$ & 10倍 & 5 & - \\
\hline 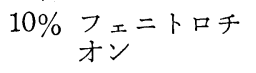 & 400 800倍 & $1 \sim 2$ & 20倍 & $25 \sim 50$ & $5 \mathrm{ml} /$ 水量 $1 \mathrm{t}$ & 20倍 & $25 \sim 50$ & 10倍 50 \\
\hline $\begin{array}{l}5 \% \text { フェニトロチ } \\
\text { オン } \\
2 \% \text { DDVP }\end{array}$ & 500倍 & 2 & 10倍 & 7.5 & $10 \mathrm{ml} /$ 水量 $1 \mathrm{t}$ & 10倍 & 7.5 & - \\
\hline $5 \%$ ジブロム & 300倍 & 2 & 10倍 & 50 & 一 & & - & - \\
\hline $\begin{array}{c}\text { 10\% ディプテレッ } \\
\text { クス }\end{array}$ & 400～600倍 & 2 & 20倍 & 50 & $15 \sim 20 \mathrm{ml} /$ 水量 $1 \mathrm{t}$ & 20倍 & 50 & - \\
\hline $\begin{array}{l}3 \% \text { ディプテレッ } \\
\text { クスス } \\
2 \% \text { DDVP }\end{array}$ & 300倍 & 2 & 10倍 & 7.5 & $20 \mathrm{ml} /$ 水量 $1 \mathrm{t}$ & 10倍 & 7.5 & - \\
\hline 10\% ナンコール & 500～700倍 & 2 & 20倍 & 50 & $5 \mathrm{ml} /$ 水量 $1 \mathrm{t}$ & 20倍 & 50 & - \\
\hline $\begin{array}{l}3 \% \text { ナソコール } \\
2 \% \text { DDVP }\end{array}$ & 300倍 & 2 & 10倍 & 5 & $10 \sim 30 \mathrm{ml} /$ 水量 $1 \mathrm{t}$ & 10倍 & 5 & - \\
\hline 5\% バイテックス & $300 \sim 500$ 倍 & 2 & 10倍 & 50 & $10 \mathrm{ml} /$ 水量 $1 \mathrm{t}$ & 10倍 & 50 & 10倍 50 \\
\hline $\begin{array}{l}5 \% \text { バイテックス } \\
2 \% \text { DDVP }\end{array}$ & 500咅 & 2 & 10倍 & 5 & $10 \mathrm{ml} /$ 水量 $1 \mathrm{t}$ & 10倍 & 5 & - \\
\hline
\end{tabular}


防疫用殺虫剤に何度か転換期のあったせいか，この表 には現在いくつかの問題点がある.

まず第一に，「ノミ」「シラミ」の欄がないことである. 元の表のこれらの欄には，DDT，リンデンが掲げられ ていたが，塩素系殺虫剤の規制で消失したためにノミ， シラミに使用できる殺虫凨がなくなってしまった．最近 シラミ類, とくにアタマジラミが学童などにふえて各地 で問題を起しているが，厚生省から許可された殺虫剤が ない現状である（ピレスロイド系の粉剤が近い将来許可 承認を受ける見込みだと聞いている).

つぎに，表 5 の乳剂に括いては，有機燐剂の蚊幼虫 (ボウフラ) に対する散布量のところで, マラソンとダイ アジノンは「水の表面積 $1 \mathrm{~m}^{2}$ 当たり何倍液を何 $\mathrm{ml}$ と いう基準，DDVP 以下の欄では「水量 1 トン当たり乳 剂原液を何 $\mathrm{ml}$ 投入」という基準となって扔り, 統一を 欠いている.

また，表 4 に，1\% バイテックス粉剤を水の表面積 $/ \mathrm{m}^{2}$ 当たり $1 \mathrm{~g}$ の割で散布してボウフラを駆除する闌がある
がこては“フローティング”粉片を指しているものだ と筆者は解釈している.

\section{殺虫剂抵抗性の問題}

現在，世界で 140 種以上の衛生害虫に殺虫剂抵抗性の 問題が生じており, 日本でもイエバェ, アカイエカ, チ カイエカ, コガタアカイエカ, チャバネゴキブリのよう な, もっとも身近かな衛生害虫に有機燐剤抵抗性が認め られている。

抵抗性が衛生害虫を防除する上に大きな障害になるケ 一スが年々ふえてきているが，対策としては交差抵抗性 がないか，交差抵抗性の度合が小さい薬剤に切りかえる 方法が奨められ，成功している．農業害虫で試みられて いる薬剤のローテーションは衛生害虫の場合はほとんど おこなわれていない実情である。実験室では，抵抗性を 打破できる酵素阻害の共力率がいくつか存在して扣り， WHO では今後こういう共力剤の添加された製剤の開発 を期待している. 